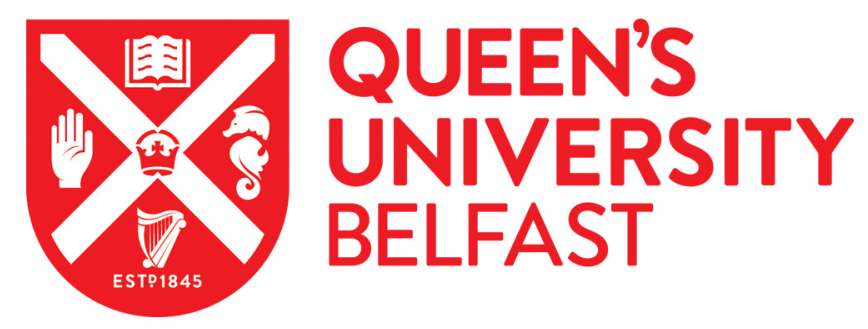

\title{
The Preboreal climate reversal and a subsequent solar-forced climate shift
}

Van Der Plicht, J., Van Geel, B., Bohncke, S. J. P., Bos, J. A. A., Blaauw, M., Speranza, A. O. M., Muscheler, R., \& Bjorck, S. (2004). The Preboreal climate reversal and a subsequent solar-forced climate shift. Journal of Quaternary Science, 19(3), 263-269. https://doi.org/10.1002/jqs.835

Published in:

Journal of Quaternary Science

Document Version:

Publisher's PDF, also known as Version of record

Queen's University Belfast - Research Portal:

Link to publication record in Queen's University Belfast Research Portal

\footnotetext{
General rights

Copyright for the publications made accessible via the Queen's University Belfast Research Portal is retained by the author(s) and / or other copyright owners and it is a condition of accessing these publications that users recognise and abide by the legal requirements associated with these rights.
}

Take down policy

The Research Portal is Queen's institutional repository that provides access to Queen's research output. Every effort has been made to ensure that content in the Research Portal does not infringe any person's rights, or applicable UK laws. If you discover content in the Research Portal that you believe breaches copyright or violates any law, please contact openaccess@qub.ac.uk. 


\title{
The Preboreal climate reversal and a subsequent solar-forced climate shift
}

\author{
J. VAN DER PLICHT, ${ }^{*}$ B. VAN GEEL, ${ }^{2}$ S. J. P. BOHNCKE, ${ }^{3}$ J. A. A. BOS, ${ }^{2}$ M. BLAAUW, ${ }^{2}$ A. O. M. SPERANZA, ${ }^{2}$ \\ R. MUSCHELER ${ }^{4}$ and S. BJÖRCK ${ }^{4}$ \\ ${ }^{1}$ Centre for Isotope Research, Radiocarbon Laboratory, University of Groningen, Nijenborgh 4, 9747 AG Groningen, \\ The Netherlands \\ ${ }^{2}$ Institute for Biodiversity and Ecosystem Dynamics, University of Amsterdam, Kruislaan 318, 1098 SM Amsterdam, The Netherlands \\ ${ }^{3}$ Department of Quaternary Geology and Geomorphology, Free University, de Boelelaan 1085, 1081 HV Amsterdam, \\ The Netherlands \\ ${ }^{4}$ Department of Geology, Quaternary Geology, Lund University, Tornavägen 13, 22363 Lund, Sweden
}

van der Plicht, J., van Geel, B., Bohncke, S. J. P., Bos, J. A. A., Blaauw, M., Speranza, A. O. M., Muscheler, R. and Björck, S. 2004. The Preboreal climate reversal and a subsequent solar-forced climate shift. J. Quaternary Sci., Vol. 19 pp. 263-269. ISSN 0267-8179.

Received 23 January 2003; Revised 4 November 2003; Accepted 7 December 2003

\begin{abstract}
Accurate chronologies are essential for linking palaeoclimate archives. Carbon-14 wiggle-match dating was used to produce an accurate chronology for part of an early Holocene peat sequence from the Borchert (The Netherlands). Following the Younger Dryas-Preboreal transition, two climatic shifts could be inferred. Around $11400 \mathrm{cal}$. yr BP the expansion of birch (Betula) forest was interrupted by a dry continental phase with dominantly open grassland vegetation, coeval with the PBO (Preboreal Oscillation), as observed in the GRIP ice core. At $11250 \mathrm{cal}$. yr BP a sudden shift increase of atmospheric ${ }^{14} \mathrm{C}$; (ii) a temporary decline of atmospheric $\mathrm{CO}_{2}$; and (iii) an increase in the GRIP ${ }^{10} \mathrm{Be}$ flux. The close correspondence with excursions of cosmogenic nuclides points to a decline in solar activity, which may have forced the changes in climate and vegetation at around 11250 cal. yr BP. Copyright (C) 2004 John Wiley \& Sons, Ltd.
\end{abstract}

to a humid climate occurred. This second change appears to be contemporaneous with: (i) a sharp Journal of Quaternary Science

KEYWORDS: Preboreal; solar forcing; climate change; peat; wiggle-match dating; ${ }^{14} \mathrm{C} ;{ }^{10} \mathrm{Be} ;{ }^{18} \mathrm{O}$.

\section{Introduction}

Lake sediments and peat deposits are valuable archives for the study of past climate change. Calendar year chronologies are of crucial importance for linking the climatic signals from different locations. Precise dating is essential for the study of leads and lags and the potential causes and effects within the climate system. In this paper we compare inferred climatic change as recorded in a European terrestrial sequence from the Borchert (from the east of The Netherlands) with Greenland ice-core data (Fig. 1). The Borchert deposits accumulated in an abandoned channel of the former Dinkel River drainage system. In this sequence, the early Holocene is recorded at high-resolution, which makes this record unique for the North Atlantic region. The detailed palynological-palaeoclimatological record from the Borchert was published by van Geel et al. (1981). Sedimentation started under lacustrine conditions during the later part of the Younger Dryas and continued to ca. 3400 yr BP. Originally the sequence was ${ }^{14} \mathrm{C}$ dated by the con-

* Correspondence to: J. van der Plicht, Centre for Isotope Research, Radiocarbon Laboratory, University of Groningen, Nijenborgh 4, 9747 AG Groningen, The Netherlands. E-mail: plicht@phys.rug.nl

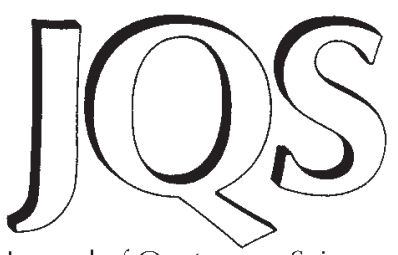
. . 


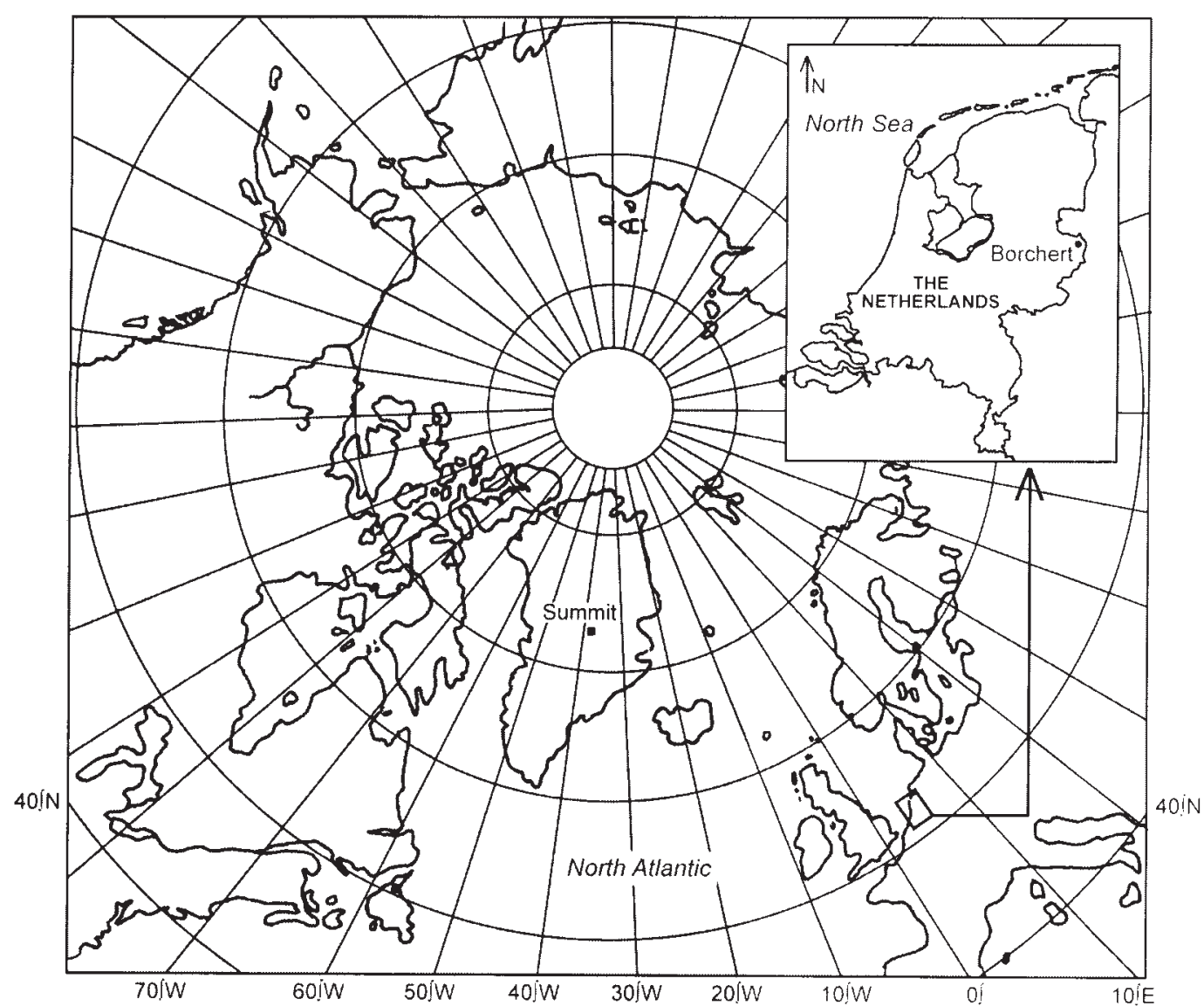

Figure 1 Map of the Northern Hemisphere, with the location of the Borchert (The Netherlands) and the Summit ice-cores GRIP/GISP2 (Greenland)

$\mathrm{KOH}$ for $10 \mathrm{~min}$; the macrofossils were washed with deionised water over a 125-140 $\mu \mathrm{m}$ sieve, until excess humic and fulvic acids were removed from the sample material. Macrofossils were picked out manually, selected for ${ }^{14} \mathrm{C}$ dating, and stored at a temperature of $4{ }^{\circ} \mathrm{C}$ in a very dilute solution of $\mathrm{HCl}$ (Kilian et al., 2000). Samples were then combusted and purified to $\mathrm{CO}_{2}$ by an automatic $\mathrm{CN}$ analyser. The $\mathrm{CO}_{2}$ produced was trapped cryogenically, and transferred into graphite by reduction under an excess of hydrogen gas (Aerts et al., 2001). The ${ }^{14} \mathrm{C}$ content of the graphite was measured by the Groningen AMS facility (van der Plicht et al., 2000), producing a radiocarbon age for every sample. Radiocarbon ages are reported in BP, defined using the international oxalic acid standard, the conventional half-life of $5568 \mathrm{yr}$, and correction for isotope effects

Table 1 AMS radiocarbon dates from the early Holocene peat sequence from the Borchert, The Netherlands. The WMD numbers correspond to the numbers in Fig. 2C. The material dated includes selected macrofossils such as fruits, seeds, catkin scales, bud scales and leafy stems of mosses

\begin{tabular}{|c|c|c|c|c|c|c|}
\hline WMD number & Sample number & Depth (cm) & Material dated & Laboratory number & $\delta^{13} \mathrm{C}$ & ${ }^{14} \mathrm{C}$ age (BP) \\
\hline 23 & 62 & 491.2 & Pinus + Betula & GrA-17590 & -25.70 & $9550 \pm 60$ \\
\hline 22 & 60 & 492.8 & Pinus + Betula & GrA-17588 & -26.31 & $9480 \pm 60$ \\
\hline 21 & 58 & 494.4 & Pinus + Betula & GrA-17578 & -26.32 & $9520 \pm 60$ \\
\hline 20 & 56 & 496.0 & Pinus + Betula & GrA-17577 & -26.76 & $9530 \pm 70$ \\
\hline 19 & 54 & 497.6 & Betula & GrA-17456 & -27.05 & $9600 \pm 60$ \\
\hline 18 & 52 & 499.2 & Betula & GrA-17576 & -26.72 & $9490 \pm 60$ \\
\hline 17 & 50 & 500.8 & Betula & GrA-17455 & -26.52 & $9610 \pm 50$ \\
\hline 16 & 48 & 502.4 & Betula & GrA-17453 & -26.70 & $9600 \pm 50$ \\
\hline 15 & 45 & 504.8 & Betula & GrA-17575 & -27.44 & $9530 \pm 60$ \\
\hline 14 & 42 & 507.2 & Betula + Populus & GrA-1715 & -26.14 & $9650 \pm 50$ \\
\hline 13 & 40 & 508.8 & Betula + Populus & GrA-1717 & -26.74 & $9700 \pm 50$ \\
\hline 12 & 38 & 510.4 & Betula + Populus & GrA-1718 & -25.99 & $9790 \pm 50$ \\
\hline 11 & $34 \mathrm{~A}$ & 513.6 & Mosses & GrA-2623 & -28.28 & $9900 \pm 60$ \\
\hline 10 & 34B & 513.6 & Betula & GrA-2654 & -26.83 & $10,200 \pm 200$ \\
\hline 8 & 31 & 516.0 & Betula & GrA-1714 & -25.78 & $9860 \pm 50$ \\
\hline 7 & 29 & 517.6 & Betula + Mosses & GrA-1712 & -25.72 & $9740 \pm 50$ \\
\hline 6 & $28 \mathrm{~A}$ & 518.4 & Mosses & GrA-2621 & -28.09 & $10050 \pm 60$ \\
\hline 5 & $28 \mathrm{~B}$ & 518.4 & Betula & GrA-2643 & -27.21 & $10070 \pm 100$ \\
\hline 4 & $26 B$ & 520.0 & Betula & GrA-2792 & -27.23 & $10400 \pm 800$ \\
\hline 3 & $26 \mathrm{~A}$ & 520.0 & Mosses & GrA-2620 & -32.89 & $9990 \pm 60$ \\
\hline 2 & 24 & 521.6 & Betula & GrA-1716 & -25.98 & $9900 \pm 50$ \\
\hline 1 & 22 & 523.2 & Betula & GrA-1713 & -27.54 & $9860 \pm 50$ \\
\hline
\end{tabular}


to $\delta^{13} \mathrm{C}=-25 \%$. $\Delta^{14} \mathrm{C}$ denotes the atmospheric ${ }^{14} \mathrm{C}$ content expressed as the per mil deviation of the ${ }^{14} \mathrm{C}$ content of the oxalic acid standard, after correction for radioactive decay and fractionation. The stable carbon isotope $\left({ }^{13} \mathrm{C}\right)$ concentrations are expressed in $\delta^{13} \mathrm{C}$, defined as the ${ }^{13} \mathrm{C} /{ }^{12} \mathrm{C}$ ratio of the sampled gas, in per mil difference to the ${ }^{13} \mathrm{C} /{ }^{12} \mathrm{C}$ ratio of the $\mathrm{CO}_{2}$ from the international carbonate standard VPDB (Mook and van der Plicht, 1999).

Individual radiocarbon ages need to be calibrated to obtain calendar ages. However, calibration often results in a probability distribution in calendar age encompassing a relatively long period, and moreover, the age distribution may show various maxima and minima. This is caused by natural variations in the atmospheric ${ }^{14} \mathrm{C}$ concentration, resulting in the so called 'wiggles' in the calibration curve (Suess, 1970). In radiocarbon sample series from high-resolution peat sequences, these ${ }^{14} \mathrm{C}$ wiggles of the calibration curve have been recognised and used for optimising the time control (van Geel and Mook, 1989; Kilian et al., 2000; Speranza et al., 2000; Mauquoy et al., 2002). In this method a series of uncalibrated AMS radiocarbon dates can be matched to the ${ }^{14} \mathrm{C}$ calibration curve, using the stratigraphical position of the ${ }^{14} \mathrm{C}$ dated samples. The WMD method is especially used for the steep parts of the calibration curve, which correspond to periods with a strongly variable $\Delta^{14} \mathrm{C}$. The recommended radiocarbon calibration curve INTCAL98 (Stuiver et al., 1998) was used for WMD of the radiocarbon samples of the Borchert sequence. Absolute ages are reported in cal. yr BP, i.e. calibrated or calendar age relative to 1950.

Botanical analysis of the Borchert sequence has been carried out previously by van Geel et al. (1981), who produced highly detailed diagrams showing both numerous microfossils and macroremains. For the pollen diagram of the Borchert, percentages of plant taxa were calculated based on a pollen sum including arboreal pollen (AP), and pollen of upland herbs including Poaceae and Cyperaceae (NAP, non-arboreal pollen). For the present paper a summary pollen diagram was constructed, showing the main trends in the groups of trees (e.g. Betula and Pinus) and shrubs, Poaceae, Ericales and other upland herbs.

Concentrations of $\mathrm{CO}_{2}$ were reconstructed by stomatal frequency analysis from fossil birch leaves by Wagner et al. (1999). Stomatal frequency is expressed in terms of stomatal density and stomatal index $(\mathrm{SI})$. The stomatal index $(\mathrm{SI})=$ [stomatal density/(stomatal density + epidermal cell density) $] \times 100$ was used as a proxy for past changes in atmospheric $\mathrm{CO}_{2}$ concentration. The analysis of stomatal parameters of leaf cuticles was performed with a computer-aided imaging system. For more details, we refer to Wagner (1998).

The ${ }^{10} \mathrm{Be}$ flux, measured in Greenland ice (GISP2), was earlier published by Muscheler et al. (2000). The ${ }^{10} \mathrm{Be}$ flux is considered to be a good measure of changes in the production rate of the cosmogenic isotopes ${ }^{14} \mathrm{C}$ and ${ }^{10} \mathrm{Be}$.

\section{Results}

\section{Palaeobotanical data}

The palynological record (Fig. 2E) shows several prominent changes in the AP/NAP ratio and dominant arboreal taxa (Betula and Pinus). The sequence starts with a transition from a predominantly open landscape to a birch (Betula) dominated forest. This is the transition between the Younger Dryas and the Preboreal biozones. During the Younger Dryas period, sandy gyttja was deposited at the sample site (Fig. 2D).
Based on changes in the AP/NAP ratio and dominant arboreal taxa, the Preboreal biozone has been further subdivided into a Friesland Phase, a Rammelbeek Phase and the Late Preboreal. The Friesland Phase (Behre, 1966) is characterised by a strong rise in the values of Betula. The macrofossil record of the Borchert (van Geel et al., 1981) indicates that it was mainly Betula pubescens that caused this increase, although Betula nana was still present within the area. The Friesland Phase was a period of rising mean summer temperatures (van Geel et al., 1981). The Betula increase is coincident with a change from a minerogenic to organic dominated sediment (Fig. 2D).

During the following Rammelbeek Phase (Wijmstra and de Vin, 1971), forest expansion was interrupted and grasses (Poaceae) dominated the regional vegetation. The contemporaneous occurrence of thermophilous plants, such as Nymphaea alba, Ceratophyllum and representatives of the Zygnemataceae, suggests relatively dry and warm summers with mean July temperatures around $13-15^{\circ} \mathrm{C}$ (van Geel et al., 1981), although winter temperatures may have been low (van Geel and Kolstrup, 1978). In climatological terms, a dry continental phase was initiated and regionally the wet birch, Betula pubescens, gave way to a steppe-like vegetation rich in grasses. A similar expansion of herbaceous vegetation also has been recognised in other pollen records from The Netherlands (Wijmstra and de Vin, 1971; Hoek, 1997) and northwest Germany (Behre, 1967). Locally, at the Borchert, the small, shallow lake filled up with Drepanocladus (moss) peat (Fig. 2D).

During the Late Preboreal, birch forest expanded again and the macrofossil record (van Geel et al., 1981) shows that Betula pendula occurred in the vegetation surrounding the site. At the transition from the Rammelbeek Phase to the Late Preboreal there is a sudden transition from Drepanocladus peat, through a brief Menyanthes-Utricularia phase, to Sphagnum peat (Fig. 2D). The local presence of Sphagnum and Assulina suggest relatively oligotrophic conditions and a rainwater-fed local vegetation. Pinus immigrated during the later part of the Late Preboreal. The transition to the Boreal biozone is characterised by the immigration of Corylus.

\section{$\mathrm{CO}_{2}$ data}

Stomatal frequency signatures of fossil birch leaves in the Borchert sequence, published by Wagner et al. (1999), reflect a sharp rise in atmospheric $\mathrm{CO}_{2}$ during the Friesland Phase (Fig. 2F). In this phase, $\mathrm{CO}_{2}$ concentrations rose from ca. 260 ppmv to 327 ppmv, followed by a more gradual increase during the Rammelbeek Phase, to ca. 336 ppmv in the early part of the Late Preboreal. After the start of the Late Preboreal there was a gradual decline to a minimum of ca. 301 ppmv. This was followed again by a strong increase to ca. 348 ppmv, before the $\mathrm{CO}_{2}$ concentrations stabilised to between 333 and 347 ppmv.

\section{Radiocarbon data}

Owing to the absence of datable material, ${ }^{14} \mathrm{C}$ measurements have not been made from the Younger Dryas interval of the Borchert sequence. However, a new series of $23 \mathrm{AMS}{ }^{14} \mathrm{C}$ dates (Table 1) have been measured from the Preboreal part. For the material dated, the ${ }^{14} \mathrm{C}$ age (in $\mathrm{BP} \pm 1 \sigma$ ) and the $\delta^{13} \mathrm{C}$ values (in \% VPDB) are listed for each depth in Table 1. The ${ }^{14} \mathrm{C}$ dates were wiggle-matched on the INTCAL98 ${ }^{14} \mathrm{C}$ calibration curve (Stuiver et al., 1998). The relevant part of the INTCAL98 calibration curve is shown as red lines ( $1 \sigma$ envelope) from ca. 11950 to 10650 cal. yr BP in Fig. $2 \mathrm{C}$. To each ${ }^{14} \mathrm{C}$ date, a 


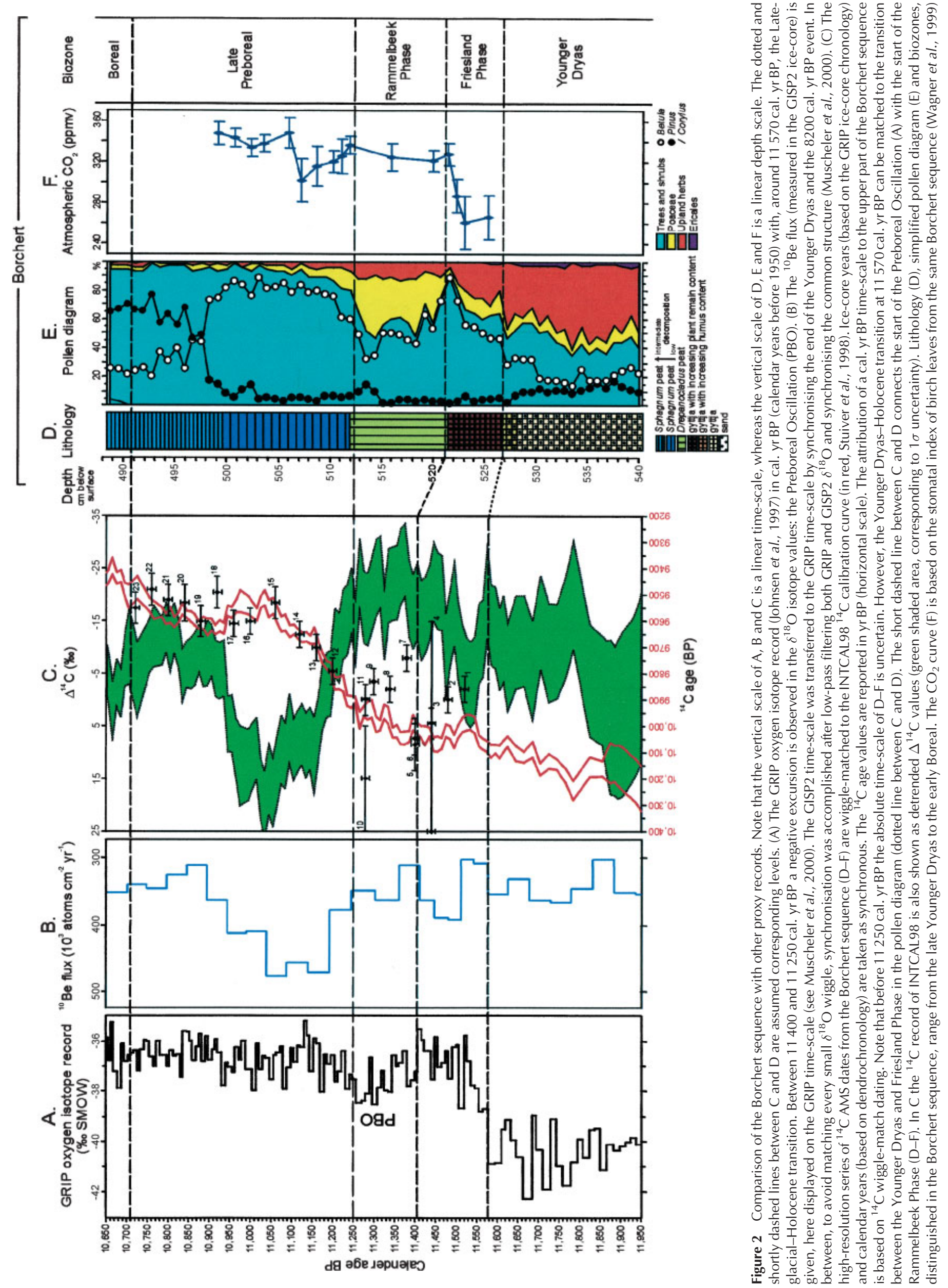


WMD number was assigned (numbers $1-23$ ). Figure 2C shows that a WMD based chronology for the sequence was obtained from ca. 11250 to $10700 \mathrm{cal}$. yr BP. Before $11250 \mathrm{cal}$. yr BP, WMD fails and thus the absolute time-scale of the Borchert sequence is uncertain. The same phenomenon was also observed in another record in The Netherlands; paradoxically, however, there are also records that seem to give a good WMD within the same time interval (Bos et al., in preparation). Possible causes for this phenomenon are currently under investigation.

The $\Delta^{14} \mathrm{C}$ data, plotted in green (Fig. 2C), have been calculated from the INTCAL98 data set. Here we use the residual or detrended $\Delta^{14} \mathrm{C}$ signal, i.e. the geomagnetic component has been subtracted (Damon and Peristykh, 2000). The green shaded area corresponds with the $1 \sigma$ uncertainty of the data. The $\Delta^{14} \mathrm{C}$ curve shows no major fluctuations during the early Preboreal period. There is a tendency, however, to more negative values during the Friesland Phase, when the residual $\Delta^{14} \mathrm{C}$ values change from ca. $-5 \%$ to ca. $-20 \%$. During the Rammelbeek Phase these values stabilise around $-22 \%$. At the beginning of the Late Preboreal, the residual $\Delta^{14} \mathrm{C}$ values rise very rapidly from ca. $-15 \%$ to positive values and reach a maximum of ca. $+15 \%$ around $11000 \mathrm{cal}$. yr BP. Later, during the Late Preboreal, the residual $\Delta^{14} \mathrm{C}$ values decrease again to around $-10 \%$.

\section{Comparison with other proxy records}

Using the dating accuracy based on WMD, the Borchert sequence was considered 'absolutely dated' from ca. 11250 to ca. $10700 \mathrm{cal}$. yr BP. This means that we are now able to compare the Borchert record directly with other proxy records, such as the $\delta^{18} \mathrm{O}$ ratio and ${ }^{10} \mathrm{Be}$ flux in Greenland ice-core records (Fig. 2A and $\mathrm{B}$ ).

The ${ }^{10} \mathrm{Be}$ flux was measured originally in the GISP2 ice-core. In Fig. 2B the GISP2 time-scale was transferred to the GRIP time-scale by synchronising the end of the Younger Dryas and the $8200 \mathrm{cal}$. yr BP event. To avoid matching every small $\delta^{18} \mathrm{O}$ wiggle (which often cannot be allocated unambigiously), the synchronisation was achieved by low-pass filtering of both GRIP and GISP2 $\delta^{18} \mathrm{O}$, and synchronising the common structure (Muscheler et al., 2000). As pointed out by Lowe et al. (2001), there are differences between the Greenland GRIP and GISP2 ice-core chronologies. However, the official (ss09) as well as the revised GRIP (ss08c) chronology suggest synchronous changes in ${ }^{10}$ Be-derived ${ }^{14} \mathrm{C}$ (Muscheler et al., 2000) and measured $\Delta^{14} \mathrm{C}$ around $11000 \mathrm{cal}$. yr BP, indicating that the GRIP time-scale agrees well with the absolute tree-ring timescale (Friedrich et al., 2001).

In Fig. 2A, B and C the vertical scale is the absolute age in cal. yr BP (calibrated years or calendar years relative to $A D$ 1950). This time-scale is valid for the ice-core records and the ${ }^{14} \mathrm{C}$ plots. The vertical scale for the palaeoecological plots of the Borchert sequence (Fig. 2D-F) is a depth scale.

The Younger Dryas-Holocene transition, which could not be dated by AMS, was present clearly in both the pollen diagram of the Borchert sequence, and the sedimentological record by a lithological change from predominantly minerogenic to organic deposits (LC; see Björck et al., 1996). This transition in the Borchert pollen diagram (Fig. 2E, for details see van Geel et al., 1981) was synchronised (dotted line between Fig. 2C and D) with the Late-glacial-early Holocene transition in the GRIP ice-core at ca. 11570 cal. yr BP (Johnsen et al., 1997). Furthermore, it is possible to connect the start of the Rammelbeek Phase (short dashed line between Fig. 2C and D) with the start of the Preboreal Oscillation in the GRIP ice-core (PBO, Fig. $2 \mathrm{~A})$. This is based on the assumption that the accumulation rate of the well preserved Drepanocladus peat, which accumulated during the Rammelbeek Phase, was considerably higher than the accumulation rate of the lacustrine deposit, which was formed during the Friesland Phase. The Rammelbeek Phase occurred during a period of lower $\Delta^{14} \mathrm{C}$ values and maximum solar insolation at $65^{\circ} \mathrm{N}$ at ca. $11000 \mathrm{cal}$. yr BP (Berger and Loutre, 1991). Botanical evidence (see previous section) points to relatively dry and warm summer conditions.

From ca. $11250 \mathrm{cal}$. yr BP onwards, the Borchert chronology is based on WMD and the ice core and Borchert time-scales (see Fig. 2) are regarded as synchronous. Figure 2B and C shows that the transition of the Rammelbeek Phase to the Late Preboreal at $11250 \mathrm{cal}$. yr BP coincides with the start of sharp rises of $\Delta^{14} \mathrm{C}$ and the ${ }^{10} \mathrm{Be}$ flux. Locally a transition from Drepanocladus to Sphagnum peat was recorded. This change indicates a hydrological transition from groundwater-fed to predominantly rainwater-fed local vegetation. Regionally the birch forest was able to expand again at the expense of open grassland vegetation. The analysis of stomatal frequencies in Betula leaves from these levels showed a temporary decline of atmospheric $\mathrm{CO}_{2}$ levels after the start of the Late Preboreal (Fig. 2F). The contemporaneous abrupt changes of the local and regional vegetation at the transition from the Rammelbeek Phase to the Late Preboreal are interpreted as the effects of a sudden shift towards wetter climatic conditions. The Late Preboreal atmospheric $\mathrm{CO}_{2}$ decline apparently followed this climate change (Fig. 2F).

\section{Discussion}

Given the dating accuracy provided by WMD, we are now able to compare climate change (as inferred from changes in local and regional vegetation composition) with atmospheric ${ }^{14} \mathrm{C}$ changes, and with Greenland ice-core data (Johnsen et al., 1997; Fig. 2A). The two cosmogenic nuclides ${ }^{14} \mathrm{C}$ and ${ }^{10} \mathrm{Be}$, show similar, contemporaneous fluctuations during the Preboreal period (Muscheler et al., 2000). These radionuclide records provide information on past solar activity, as the galactic cosmic ray flux, which produce ${ }^{14} \mathrm{C}$ and ${ }^{10} \mathrm{Be}$ in the atmosphere, is modulated by geo- and heliomagnetic shielding. Whereas ${ }^{14} \mathrm{C}$ enters the global carbon cycle in the form of ${ }^{14} \mathrm{CO}_{2}$, which exchanges with the biosphere and the oceans, ${ }^{10} \mathrm{Be}$ attaches to aerosols deposited mainly by precipitation (McHargue and Damon, 1991). The close correspondence between the ${ }^{10} \mathrm{Be}$ flux (Fig. 2B) and the residual $\Delta^{14} \mathrm{C}$ record (Fig. 2C) shows that a changing production rate was the major factor influencing the fluctuations in both cosmogenic nuclide records, most probably caused by changes in solar activity (Beer et al., 1988).

In the early Preboreal part of the Greenland ice-cores (Fig. 2A), a negative excursion is recorded in the $\delta^{18} \mathrm{O}$ isotope values between 11400 and $11250 \mathrm{cal}$. yr BP, which is interpreted as a cool climatic phase (Kapsner et al., 1995; Björck et al., 1996), i.e. the Preboreal Oscillation (PBO). In the ice cores the PBO is a phase of diminished snow accumulation. It has been attributed to a meltwater pulse, caused by the melting of the Scandinavian ice-sheets, including the drainage of the Baltic Ice Lake (Björck et al., 1997; Hald and Hagen, 1998) and drainage of Lake Agassiz (Fisher et al., 2002). This was suggested to result in a temporary decrease of the thermohaline circulation in the North Atlantic.

In the North Atlantic terrestrial record the PBO is positioned between the $10000-9900$ and $9600-9500{ }^{14} \mathrm{C}$ yr BP plateaus 
(Björck et al., 1996, 1997). It is synchronous with a significant rise in atmospheric $\Delta^{14} \mathrm{C}$ as shown in Fig. 2C. Björck et al. (1996, 1997) interpreted the fluctuations in the Greenland ice-cores and North Atlantic terrestrial data sets as one event, the PBO. However, the Borchert record suggests that the early Preboreal may have been characterised by two distinct climatic events, caused by different processes. Initially there is a phase, which in the Greenland ice-cores was recorded as a minimum in the oxygen isotope record, i.e. the defined Preboreal Oscillation. This was possibly caused by a large meltwater flux that resulted in a temporary decrease of the thermohaline circulation. The northwest European terrestrial equivalent of this phase may have been dry and continental, i.e. the Rammelbeek Phase. The second phase, characterised by the rise in cosmogenic nuclides ${ }^{14} \mathrm{C}$ and ${ }^{10} \mathrm{Be}$ and by $\delta^{18} \mathrm{O}$ rising again, starts at $11250 \mathrm{cal}$. yr BP, and correlates with the 'European terrestrial PBO' as defined by Björck et al. (1997). This shift to more humid conditions in northwest Europe at $11250 \mathrm{cal}$. yr BP could have been triggered by a sudden decline of solar activity leading to a sharp rise of cosmic ray intensity, which is shown by both the $\Delta^{14} \mathrm{C}$ record and the ${ }^{10}$ Be flux (Fig. 2B and C).

More evidence for abrupt changes to wetter climatic conditions in the temperate zones at the onset of sudden increases of $\Delta^{14} \mathrm{C}$ have come from raised bog studies (van Geel et al., 1998) and lake-level studies (Magny, 1993). Major climate shifts date to 2750 cal. yr BP (van Geel et al., 1998) and the 'Little Ice Age' (Mauquoy et al., 2002). For these middle and late Holocene climatic events it was postulated that they were caused by variations in solar activity. In earlier studies (Denton and Karlén, 1973; Stuiver and Braziunas, 1989; Magny, 1993; Björck et al., 1997) it was suggested that rises of atmospheric ${ }^{14} \mathrm{C}$, contemporaneous with cooling phases during the Late Glacial and early Holocene, were the result of a decreased thermohaline circulation, the consequence of episodic outbursts of large meltwater reservoirs into the North Atlantic.

Based on the Borchert Preboreal record, a different, less 'oceanocentric', but 'heliocentric' conclusion is proposed (van Geel et al., 2003): decreased solar activity was responsible for the sharp increases of the cosmogenic nuclides, and may also have been the trigger for the climate shift (cf. Björck et al., 2001; Bond et al., 2001). In principle, the $\Delta^{14} C$ changes may also have been caused by changes in ocean circulation. However, the $\Delta^{14} \mathrm{C}$ signal lacks sensitivity to changes in the thermohaline circulation. Carbon cycle models indicate a change of $40 \%$ or less during the Younger Dryas (see e.g. Marchal et al., 2001). This change may have lasted for approximately $1200 \mathrm{yr}$. Most probably the ocean ventilation changes at the time of the PBO are smaller in magnitude and of shorter duration compared with the Younger Dryas. Therefore, the ocean circulation related $\Delta^{14} \mathrm{C}$ change around the $\mathrm{PBO}$ is expected to be much smaller and not detectable in the ${ }^{14} \mathrm{C}$ record. Furthermore, the synchronicity between the ${ }^{10} \mathrm{Be}$ and ${ }^{14} \mathrm{C}$ records and the quantitative agreement of both ${ }^{10} \mathrm{Be}-$ and tree-ring-based $\Delta^{14} C$ (Muscheler et al., 2000) confirms that the rise of atmospheric ${ }^{14} \mathrm{C}$ was caused by an increased production of cosmogenic nuclides. This change is most likely the result of a change in solar activity. Therefore, these changes suggest a cause of the recorded climate shift: although reduced solar activity may have triggered the climate change, a contemporaneous decrease in solar wind increased the cosmic ray flux impinging on the upper atmosphere, resulting in an increased production of ${ }^{14} \mathrm{C}$ and ${ }^{10} \mathrm{Be}$. Nevertheless, oceanic and $\mathrm{CO}_{2}$ changes can amplify the solar-induced changes.

There are additional mechanisms that could amplify climate changes owing to a decline in solar activity. It has been proposed that reduced solar UV intensity may cause a decline of stratospheric ozone production and cooling as a result of less absorption of solar radiation. This might influence atmospheric circulation patterns (extension of Polar Cells and equatorward relocation of mid-latitude storm tracks (Haigh, 1996; van Geel et al., 2001). Increased cosmic ray intensity might also influence climate via stimulated formation of low clouds and precipitation (Svensmark and Friis-Christensen, 1997; Carslaw et al., 2002).

\section{Conclusion}

Previously, accurate dating and comparison of Preboreal climatic oscillations in terrestrial records was problematic. However, by using the dating precision based on WMD, it is now possible to compare palaeoecological data in great detail with the fluctuations of cosmogenic isotopes, and with the oxygen isotope records in Greenland ice-cores. This study demonstrates that the early Preboreal climate history of northwestern Europe was complex; a continental climate with warm, dry summers and cold winter conditions of the Rammelbeek Phase was coeval with cooling (PBO) in Greenland. The onset of a more humid period at $11250 \mathrm{cal}$. yr BP in northwest Europe coincides with a return to normal interglacial conditions over Greenland as well as with a significant decline in solar activity. The data presented form an indication for a link between changes in solar activity and climate change. Based on the data available, it is also concluded that the atmospheric $\mathrm{CO}_{2}$ fluctuations, as reconstructed from the stomatal index of birch leaves in the same peat deposit, followed climate change.

Acknowledgements The investigations were (in part) supported by the Research Council for Earth and Life Sciences (ALW) with financial aid from The Netherlands Organisation for Scientific Research (NWO). The authors thank two anonymous reviewers for their comments. Dan Yeloff kindly improved the English.

\section{References}

Aerts-Bijma AT, van der Plicht J, Meijer HAJ. 2001. Automatic AMS sample combustion and $\mathrm{CO}_{2}$ collection. Radiocarbon 43: 293-298. Beer J, Siegenthaler U, Bonani G, Finkel RC, Oeschger H, Suter M, Wölfli W. 1988. Information on past solar activity and geomagnetism from ${ }^{10} \mathrm{Be}$ in the Camp Century icecore. Nature 331: 675-679.

Behre KE. 1966. Untersuchungen zur spätglazialen und frühpostglazialen Vegetationsgeschichte Ostfrieslands. Eiszeitalter und Gegenwart 17: 69-84.

Behre KE. 1967. The Late Glacial and Early Postglacial history of vegetation and climate in northwestern Germany. Review of Palaeobotany and Palynology 4: 149-161.

Berger A, Loutre MF. 1991. Insolation values for the climate of the last 10 million years. Quaternary Science Reviews 10: 297-317.

Björck S, Kromer B, Johnsen SJ, Bennike O, Hammarlund D, Lehmdahl G, Possnert G, Rasmussen TL, Wohlfarth B, Hammer CU, Spurk M. 1996. Synchronised terrestrial-atmospheric deglacial records around the North Atlantic. Science 274: 1155-1160.

Björck S, Rundgren M, Ingólfsson O, Vunder S. 1997. The Preboreal oscillation around the Nordic Seas: terrestrial and lacustrine responses. Journal of Quaternary Science 12: 455-466.

Björck S, Muscheler R, Kromer B, Andresen CS, Heinemeier J, Johnsen SJ, Conley D, Koc N, Spurk M, Veski S. 2001. High-resolution analysis of an early-Holocene climate event may imply decreased solar forcing as an important climate trigger. Geology 29: 1107-1110.

Bond G, Kromer B, Beer J, Muscheler R, Evans MN, Showers W, Hoffmann S, Lotti-Bond R, Hajdas I, Bonani G. 2001. Persistent solar 
influence on North Atlantic climate during the Holocene. Science 294: $2130-2136$.

Carslaw KS, Harrison RG, Kirkby J. 2002. Cosmic rays, clouds, and climate. Science 298: 1732-1737.

Damon PE, Peristykh AN. 2000. Radiocarbon calibration and application to Geophysics, Solar Physics, and Astrophysics. Radiocarbon 42: 137-150.

Denton GH, Karlén W. 1973. Holocene climatic variations-their pattern and possible cause. Quaternary Research 3: 155-205.

Fisher TG, Smith DG, Andrews JT. 2002. Preboreal oscillation caused by a glacial Lake Agassiz flood. Quaternary Science Reviews 21: 873-878.

Friedrich M, Kromer B, Kaiser FK, Spurk M, Hughen KA, Johnsen SJ. 2001. High-resolution climate signals in the Bolling-Allerod Interstadial (Greenland Interstadial 1) as refelected in Euopean tree-ring chronologies to marine varves and ice-core records. Quaternary Science Reviews 20: 1223-1232.

Hald M, Hagen S. 1998. Early Preboreal cooling in the Nordic seas region triggered by meltwater. Geology 26: 615-618.

Haigh JD. 1996. The impact of solar variability on climate. Science 272: 981-984.

Hoek WZ. 1997. Palaeogeography of Lateglacial vegetations. PhD thesis, Vrije Universiteit Amsterdam.

Johnsen SJ, Clausen HB, Dansgaard W, Gundestrup NS, Hammer CU, Andersen U, Andersen KK, Hvidberg CS, Dahl-Jensen D, Steffensen JP, Shoji H, Sveinbjörnsdóttir AE, White JWC, Jouzel J, Fisher D. 1997. The $\delta^{18} \mathrm{O}$ record along the Greenland Ice Core Project deep ice core and the problem of possible Eemian climate instability. Journal of Geophysical Research 102: 26397-26410.

Kapsner WR, Alley RB, Shuman CA, Anandakrishnan S, Grootes PM. 1995. Dominant influence of atmospheric circulation on snow accumulation in Greenland over the last 18000 years. Nature 373: 52-54.

Kilian MR, van Geel B, van der Plicht J. 2000. ${ }^{14} \mathrm{C}$ AMS wiggle matching of raised bog deposits and models of peat accumulation. Quaternary Science Reviews 19: 1011-1033.

Lowe JJ, Hoek WZ, INTIMATE group. 2001. Inter-regional correlation of palaeoclimatic records for the Last Glacial-Interglacial Transition: a protocol for improved precision recommended by the INTIMATE group. Quaternary Science Reviews 20: 1175-1187.

Magny M. 1993. Solar influences on Holocene climatic changes illustrated by correlations between past lake-level fluctuations and the atmospheric ${ }^{14} \mathrm{C}$ record. Quaternary Research 40: 1-9.

Magny M. 2004. Holocene climate variability as refelected by mid-European lake-level fluctuations and its probable impact on prehistoric human settlements. Quaternary International 113: 65-79.

Marchal O, Stocker TF, Muscheler R. 2001. Atmospheric radiocarbon during the Younger Dryas: Production, ventilation, or both? Earth and Planetary Science Letters 185: 383-395.

Mauquoy D, van Geel B, Blaauw M, van der Plicht J. 2002. Evidence from northwest European bogs shows 'Little Ice Age' climate changes driven by variations in solar activity. The Holocene 12: 1-6.

McHargue LR, Damon PE. 1991. The Global Beryllium-10 cycle. Review of Geophysics 29: 141-158.

Mook WG, Streurman HJ. 1983. Physical and chemical aspects of radiocarbon dating. PACT 8: 31-55.
Mook WG, van der Plicht J. 1999. Reporting ${ }^{14} \mathrm{C}$ activities and concentrations. Radiocarbon 41: 227-239.

Muscheler R, Beer J, Wagner G, Finkel RC. 2000. Changes in deepwater formation during the Younger Dryas event inferred from ${ }^{10} \mathrm{Be}$ and ${ }^{14} \mathrm{C}$ records. Nature 408: $567-570$.

Speranza A, van der Plicht J, van Geel B. 2000. Improving the time control of the Subboreal/Subatlantic transition in a Czech peat sequence by ${ }^{14} \mathrm{C}$ wiggle-matching. Quaternary Science Reviews 19: $1589-1604$.

Stuiver M, Braziunas TF. 1989. Atmospheric ${ }^{14} \mathrm{C}$ and century-scale oscillations. Nature 338: 405-408.

Stuiver M, Reimer PJ, Bard E, Beck JW, Burr GS, Hughen KA, Kromer B, McCormac G, van der Plicht J, Spurk M. 1998. INTCAL98 Radiocarbon age calibration. Radiocarbon 40: 1041-1083.

Suess HE. 1970. The three causes of the secular ${ }^{14} \mathrm{C}$ fluctuations, their amplitudes and time constants. In Proceedings of the 12th Nobel Symposium, Olsson IU (ed.), Stockholm; 595-605.

Svensmark H, Friis-Christensen E. 1997. Variation of cosmic ray flux and global cloud coverage - a missing link in solar-climate relationships. Journal of Atmospheric and Solar-Terrestrial Physics 59: $1225-1232$.

van der Plicht J, Wijma S, Aerts AT, Pertuisot MH, Meijer HAJ. 2000. The Groningen AMS facility: status report. Nuclear Instruments and Methods B172: 58-65.

van Geel B, Kolstrup E. 1978. Tentative explanation of the Lateglacial and Early Holocene climatic changes in north-western Europe. Geologie en Mijnbouw 57: 87-89.

van Geel B, Mook WG. 1989. High-resolution ${ }^{14} \mathrm{C}$ dating of organic deposits using natural atmospheric ${ }^{14} \mathrm{C}$ variations. Radiocarbon 31 : $151-155$

van Geel B, Bohncke SJP, Dee H. 1981. A palaeoecological study of an Upper Late Glacial and Holocene sequence from 'de Borchert', the Netherlands. Review of Palaeobotany and Palynology 31: 367-448. van Geel B, van der Plicht J, Kilian MR, Klaver ER, Kouwenberg JHM, Renssen H, Reynaud-Farrera I, Waterbolk HT. 1998. The sharp rise of $\Delta^{14} \mathrm{C}$ ca. $800 \mathrm{cal} \mathrm{BC}$ : possible causes, related climatic connections and the impact on human environments. Radiocarbon 40: 535-550.

van Geel B, Renssen H, van der Plicht J. 2001. Evidence from the past: solar forcing of climate change by way of cosmic rays and/or by solar UV? In Proceedings Workshop on Ion-Aerosol-Cloud Interactions, Kirkby J (ed.), CERN 001-007, Geneva, Switzerland 18-20 April 2001; 24-29.

van Geel B, van der Plicht J, Renssen H. 2003. Major $\Delta^{14}$ C excursions during the late glacial and early Holocene: changes in ocean ventilation or solar forcing of climate change? Quaternary International 105: 71-76.

Wagner F. 1998. The influence of environment on the stomatal frequency in Betula. PhD thesis, Utrecht University.

Wagner F, Bohncke SJP, Dilcher DL, Kürschner WM, van Geel B, Visscher H. 1999. Century-scale shifts in Early Holocene atmospheric $\mathrm{CO}_{2}$ concentration. Science 284: 1971-1973.

Wijmstra TA, de Vin A. 1971. The Dinkel canal section. In Upper Quaternary of the Dinkel valley, van der Hammen T, Wijmstra TA (eds). Mededelingen Rijks Geologische Dienst, N.S. 22: 101-129. 